\title{
Estimation of Antioxidant Activity and Total Phenol, Flavonoid Content among Natural Populations of Caper (Capparis moonii, Wight) from Western Ghats Region
}

\author{
Pallavi Yadav ${ }^{1}$ and Nutan Malpathak ${ }^{2^{*}}$ \\ 1, 2Department of Botany, Savitribai Phule Pune University, Ganeshkhind Road, Pune, INDIA.
}

\begin{abstract}
Antioxidant activity (\%) of Capparis moonii, Wight leaves and stem collected from Amboli, Western Ghat (India) was measured using DPPH , Phosphmolybdenum reduction, FRAP, Reducing power assay and $\mathrm{H}_{2} \mathrm{O}_{2}$ radical scavenging assay along with its total phenol and flavanoid content. Current research focuses on exploring antioxidants of plant origin. Method: In this study, the antioxidant activity of hexane, chloroform, ethylacetate, methanol and aqueous crude extracts of leaves and stem of Capparis moonii were evaluated by above mentioned various antioxidant assays. The various antioxidant activities were compared to standard antioxidants such as butylated hydroxytoluene (BHT) and Ascorbic acid. Phenolic and Flavanoid content was correlated with antioxidant activity. Results: Crude extracts were found to be more effective as compared to standard antioxidants like ascorbic acid and BHT. No correlation was observed between the antioxidant activities of various extracts of leaves and stem of Capparis moonii and total phenol, flavanoid content. Conclusion: The antioxidant activities of the plant extracts largely depend on the composition, concentration of the extracts, conditions of the test system and synergestic action of secondary metaboltes.
\end{abstract}

Key words: Phenols, Flavanoids, Antioxidant activity, Capparis moonii, Wight.

\section{INTRODUCTION}

Antioxidant is a compound that protects biological systems against the harmful effects of processes or reactions that can cause excessive oxidation. ${ }^{1}$ Oxidative damage caused by free radicals and ROS is the reason for aging, cancer and occurrence of other diseases. ${ }^{2}$ Antioxidants of natural origin are preferred over synthetic due to synthetic antioxidants having toxicological effects. Therefore, current research focuses on exploring antioxidants of plant origin. Since nature is storehouse of infinite molecules having therapeutic value, bioprospecting of natural resources holds prospect in identifying lead molecules or consortia of molecules with potent therapeutic properties.
Genus Capparis is well known for ethno medicinal importance. In Arab traditional system of medicines, C. spinosa is used for the treatment of various human disorders like gastro-intestinal problems, hypertension, strangury, inflammation, emmenagogue, anemia, liver dysfunction, rheumatism, dropsy, diabetes. ${ }^{3,4}$ Capparis zeylanica is ethno medicinally used in ailments like spasmolyte, blisters, boils, pneumonia, cholera, dysentery. ${ }^{5,6}$ Capparis species are reported to be utilized as contemporary ethno medicines. Species like sepiaria, flexulosa, decidua, zeylanica, baducca, tomentosa, borrida, acuminata, pyrifolia, cordata, ovalifolia are used in treating numerous diseases. ${ }^{6}$
Submission Date : 04-02-2016 Revision Date : :29-02-2016 Accepted Date : :24-03-2016

DOI: 10.5530/ijper.50.3.25

Correspondence: Nutan Malpathak

Department of Botany, SavitribaiPhule Pune University, Ganeshkhind Road, Pune, INDIA.

E-mail:mpathak@unipune. ac.in

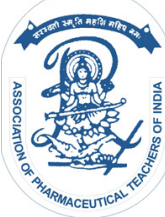

www.ijper.org 
Capparis moonii, Wight belongs to the family Capparidaceae frequently found in the Konkan regions and grows vigorously in hot semi-arid conditions. ${ }^{6}$ Its worldwide distribution is restricted to only Indian Subcontinent i.e. southern India, Sri Lanka exhibiting its endemism. ${ }^{7}$ Capparidaceae family comprising different species of Capparis is distributed in tropical and sub- tropical India, whose medicinal usage has been reported in the traditional systems of medicine. Plants belonging to the Capparidaceae family have been described as a rasayana herb and have been used extensively as an adaptogen to increase the non-specific resistance of antioxidant and immunostimulant effects. ${ }^{8}$ Capparis moonii, Wight commonly known as Waghati in Marathi and Rudanti in Sanskrit. Therapeutic Uses of Rudanti are described in Ayurveda. Rudanti nourishes each and every cell of the body (Rasayani). It is useful in under nutrition and emaciating conditions (Shoshghani). Signs of aging (Jara Vinashnam) are delayed by use of rudanti and is also useful in diseases which are having devastating effects on all the systems of the body (Rajyakshma Shasyate). Rudanti was widely used to get relief from asthma and cough. ${ }^{9}$ Due to significant ethno medicinal importance of genus capparis, Capparis moonii, Wight emerges as an extremely valuable plant for bioprospecting.

In the present study, the antioxidant activity of hexane, chloroform, ethyl acetate, methanol and aqueous crude extracts of leaves and stem of Capparis moonii were evaluated by above mentioned various antioxidant assays like DPPH, Phosphmolybdenum reduction, FRAP, Reducing power assay and $\mathrm{H}_{2} \mathrm{O}_{2}$ radical scavenging assay. The various antioxidant activities were compared with standard antioxidants such as BHT and Ascorbic acid. Correlation analysis was studied between the antioxidant activities of various extracts of leaves and stem of Capparis moonii and total phenol, flavanoid content.

\section{MATERIALS}

The stem and leaves of Capparis moonii was collected freshly from Amboli, district Sindhudurg ,Maharashtra (India) in the month of April, 2012 and was authenticated from Botanical Survey of India, Western Circle, Pune (Registration no BSI/WRC/Tech./2012/ and Voucher no PAYCAM 1).

\section{Chemicals}

2,2-Diphenyl-2-picrylhydrazyl (DPPH), 2,4,6-tripyridyl$s$-triazine (TPTZ), potassium ferricyanide, potassium persulfate, trichloroacetic acid, tannic acid, rutin, $\mathrm{FeCl}$, ascorbic acid, and butylated hydroxyl toluene (BHT) were purchased from HIMEDIA Laboratories Pvt. Ltd.
(Germany); Folin-Ciocalteau phenol reagent, anhydrous sodium carbonate $\left(\mathrm{Na}_{2} \mathrm{CO}_{3}\right)$, hydrochloric acid $(\mathrm{HCl})$, glacial acetic acid, potassium chloride, sodium acetate trihydrate and solvent methanol were obtained from Merck Chemical Supplies (Damstadt, Germany).

\section{METHOD}

\section{Extract preparation}

The collected plant material was cleaned, dried under shade at room temperature and powdered. The powdered material was subjected to sequential extraction along with sonication. Solvents used for sequential extraction are Hexane, Chloroform, Ethyl acetate, Methanol and Water. $10 \mathrm{~g}$ of powdered material was soaked in $100 \mathrm{ml}$ of solvent and sonicated for $20 \mathrm{~min}$ followed by filtration using Whatmans filter paper. The extract was concentrated using rotavapor and further stored at $-4^{\circ} \mathrm{C}$ until use. The residue obtained after filtration was subjected to extraction exhaustively.

\section{Phytochemical analysis}

The extracts of Capparis moonii were subjected to different chemical tests for the detection of phytoconstituents such as carbohydrates, glycosides, alkaloids, proteins, tannins, phenolics, saponins, steroids. ${ }^{10,11}$

\section{Tests for carbohydrates}

The carbohydrates were tested by using Benedict's test, Fehling's test and Molisch test.

\section{Tests for glycosides}

Keller Kiliani Test was used for the analysis of glycosides.

\section{Tests for alkaloids}

The alkaloids have been tested by using Dragendroff's test and Wagner's test.

\section{Test for proteins}

Various extracts were dissolved in few $\mathrm{ml}$ of water and treated with Millon's reagent.

\section{Tests for tannins}

Test for tannins was performed by adding 2-3 drops of ferric chloride to $1 \mathrm{ml}$ of extract for the formation of a dark blue or greenish black colour product which shows the presence of tannins.

\section{Test for saponins}

The procedure adopted for the identification of saponins was to take $1 \mathrm{ml}$ of extract which is diluted with $20 \mathrm{ml}$ distilled water and then shaken in a graduated cylinder 
for 15 minutes. A $1 \mathrm{~cm}$ layer of foam indicates the presence of saponins.

\section{Tests for steroids}

The steroids were tested by using Libermann-Burchard test.

\section{Determination of total Phenolics}

Total phenol content in the extracts was determined by using modified Folin-Ciocalteau method. ${ }^{12}$ Absorbance of the solution was measured at $765 \mathrm{~nm}$. Total phenolic content was expressed as $\mathrm{mg} / \mathrm{g}$ tannic acid equivalent using the following equation based on the calibration curve: $y=0.1216 \times x\left(r^{2}=0.9365\right)$, where $x$ was the absorbance and $\mathrm{y}$ was the Tannic acid equivalent $(\mathrm{mg} / \mathrm{g})$.

\section{Determination of total Flavonoids}

Estimation of the total flavonoids in the plant extracts was carried out using the method of Ordon et al, 2006. ${ }^{13}$ The absorbance of the solution was measured at $420 \mathrm{~nm}$ and yellow color indicated the presence of flavonoids. Total flavonoid content was calculated as quercetin $(\mathrm{mg} / \mathrm{g})$ using the following equation based on the calibration curve: $y=0.0255 x\left(r^{2}=0.9812\right)$, where $x$ was the absorbance and $\mathrm{y}$ was the rutin equivalent $(\mathrm{mg} / \mathrm{g})$.

\section{DPPH radical scavenging assay}

The effect of the extracts on DPPH radical was estimated using the method of Miliauskas et al, 2004. ${ }^{14}$ The absorbance of the mixture was measured spectrophotometrically at $517 \mathrm{~nm}$ using Ascorbic acid as reference. The ability to scavenge DPPH radical was calculated by the following equation: DPPH radical scavenging activity $(\%)=[($ Abs Control - Abs Sample $)] /$ (Abs Control)] $\times 100$ where; Abs Control is the absorbance of DPPH radical methanol; Abs Sample is the absorbance of DPPH radical+sample extract/standard.

\section{Phosphomolybdenum assay}

The total antioxidant capacity of extracts was evaluated by method of Prieto et al, 1999 and expressed as equivalents of ascorbic acid ( $\mu \mathrm{mol} / \mathrm{g}$ of extract). ${ }^{15}$ Analiquot of $0.1 \mathrm{ml}$ of sample solution was combined in an Eppendorf tube with $1 \mathrm{ml}$ of reagent solution (0.6 M sulfuric acid, $28 \mathrm{mM}$ sodium phosphate, and 4 $\mathrm{mM}$ ammonium molyb date). The tubes were capped and incubated in a thermal block at $95^{\circ} \mathrm{C}$ for $90 \mathrm{~min}$. After the samples had cooled to room temperature, the absorbance of the aqueous solution of each was measured at $695 \mathrm{~nm}$ against a blank. A typical blank solution contained $1 \mathrm{ml}$ of reagent solution and the appropriate volume of the same solvent used for the sample, and it was incubated under the same conditions as the rest of the samples.

\section{Ferric reducing antioxidant power (FRAP) assay}

The FRAP assay was conducted using method of Wong et al, 2006. ${ }^{16}$ The increase in absorbance was measured using spectrophotometer at $593 \mathrm{~nm}$. The percent of antioxidant was calculated using the formula, percent of antioxidant $(\%)=[($ Abs Sample - Abs Control $) /$ Abs Sample] $\times 100$.

\section{Reducing Power Assay}

The reducing power was determined according to a described procedure Ferreira et al, 2007. ${ }^{17}$ Various concentrations of sample extracts $(2.5 \mathrm{~mL})$ were mixed with $2.5 \mathrm{~mL}$ of $200 \mathrm{mmol} / \mathrm{L}$ sodium phosphate buffer $(\mathrm{pH}$ 6.6) and $2.5 \mathrm{~mL}$ of $1 \%$ potassium ferricyanide. The mixture was incubated at $50^{\circ} \mathrm{C}$ for $20 \mathrm{~min}$. After incubation $2.5 \mathrm{~mL}$ of $10 \%$ trichloroacetic acid (w/v) were added and then the mixture was centrifuged at $1000 \mathrm{rpm}$ in a refrigerated centrifuge for $8 \mathrm{~min}$. The upper layer $(5 \mathrm{~mL})$ was mixed with $5 \mathrm{~mL}$ of deionised water and $1 \mathrm{~mL}$ of $0.1 \%$ of ferric chloride, and the absorbance was measured spectrophotometrically at $700 \mathrm{~nm}$.

\section{$\mathrm{H}_{2} \mathrm{O}_{2}$ radical scavenging assay}

The ability of the extract to scavenge hydrogen peroxide was determined according to the method given by Ruch et al. ${ }^{18}$ A solution of hydrogen peroxide $(2 \mathrm{mmol} / \mathrm{l})$ was prepared in phosphate buffer ( $\mathrm{pH}$ 7.4). Extracts $(50 \mu \mathrm{g} / \mathrm{ml})$ were added to hydrogen peroxide solution $(0.6 \mathrm{ml})$. Absorbance of hydrogen peroxide at $230 \mathrm{~nm}$ was determined after 10 min against a blank solution containing phosphate buffer without hydrogen peroxide and compared with ascorbic acid, the reference compound.

\section{Statistical analysis}

The data were subjected to a one-way analysis of variance (ANOVA) and the significance of the difference between means was determined by Duncan's multiple range test $(\mathrm{P}<0.05)$ using SPSS 16.0. Values are expressed as mean \pm standard deviation.

\section{RESULTS}

Hexane, Chloroform, Ethyl acetate extracts of stem and leaves showed presence of steroids and alkaloids in preliminary phytochemical investigations. Proteins and Tannins were present in methanolic and aqueous extracts. Saponins were present only in aqueous extracts. Carbohydrates were present in chloroform, methanol 
and aqueous extracts. Chloroform, Ethyl acetate and Methanol showed presence of glycosides.

Analysis of phenolic content was done by Folin- Ciocalteau method and expressed in terms of tannic acid equivalents. Table 1 denotes presence of highest phenolic content in hexane stem extract (16.19 mg TAE/ g dry wt) followed by chloroform leaves extract (15.57 mg TAE/g dry wt). Flavanoid content was determined by Aluminium chloride method spectrophotometrically. Chloroform leaves extract showed maximum flavanoid content (2.52 $\mathrm{mg}$ rutin equivalents/g dry wt) as shown in Table 1.

The proton radical scavenging action is known to be one of the various mechanisms for measuring antioxidant activity. Figure 1 shows 50\% inhibitory concentration of extracts $\left(\mathrm{IC}_{50}\right)$. The radical scavenging activity was calculated and accordingly extract concentration for $50 \%$ Inhibitory activity was determined. Methanolic stem extract showed least $\mathrm{IC}_{50}$ value (31.83) thereby determining potent radical scavenging ability almost equivalent to standard Ascorbic acid activity.

The phosphomolybdenum assay method is based on the reduction of Mo (VI) to Mo (V) by the antioxidant $\operatorname{com} \neg$ pounds and the formation of a green $\mathrm{Mo}(\mathrm{V}) \mathrm{com}-$ plex, which has a maximal absorption at $695 \mathrm{~nm}$. Figure 2 exhibits methanolic leaves extract with highest antioxidant capacity (41.57\%).

The ferric reducing ability of methanolic stem extract of Capparis moonii was highest as demonstrated in Figure 3. Similarly methanolic leaves extract proved to have strong capacity to reduce ferric ions as compared to other extracts of leaves. Among all the tested extracts for reducing power assay hexane leaves extract showed maximum activity amongst the tested plant extracts of varied polarity as shown in Figure 4. Standard antioxidant BHT showed highest activity than any other tested extracts for reducing power assay.

The scavenging ability of different extracts of C. moonii on hydrogen peroxide is shown in Figure 5 and compared with BHT as standard. Ethyl acetate leaves and stem extract possessed $22 \%$ and $21 \%$ antioxidant potential which was highest among other tested extracts.

\section{DISCUSSION}

Our findings suggest that crude extracts are more potent than antioxidant standards like ascorbic acid and BHT. Methanolic extracts showed better activity as compared to other tested extracts. These results are in agreement with previous studies done by Fejes et al where Methanolic extracts from parsley leaves found to exhibit considerable antioxidant activity against lipid peraoxida- tion. ${ }^{19}$ Study of crude extracts is significant as synergestic action of metabolites is very important attribute of crude extracts. Strong nematocidal activity of turmeric was attributed to synergestic action of curcuminiods whereas pure curcuminiods proved to be ineffective against nematocides. ${ }^{20}$ Synergism is very interesting property from drug development point of view. ${ }^{21}$ Efficacy of biologically active compounds depends upon synergestic interactions with other components. ${ }^{22}$ Multicomponent therapeutics is a new strategy to overcome one disease-one target- one drug strategy which often fails as pathogenesis of diseases involves multiple factors. ${ }^{23,24}$ Multicomponent therapeutics modulates biological networks modestly and thereby overcome complex diseases. ${ }^{25}$ Moreover many compounds are powerful in combination than alone. For example the combination of Realgar, Indigo naturalis, Radix salvia miltiorrbizae and Radix pseudostellariae constitute a formula in TCM that has proven effective against humanpromyelocytic leukemia. ${ }^{26}$ The radical scavenging and antioxidant properties of isolated metabolites demonstrate that the antioxidant properties of isolated metabolites cannot be ascribed exclusively to one class of secondary metabolitesz. The synergy of natural products renders antioxidant activity. ${ }^{27}$ Also several studies report that plant polyphenols alongwith other

Table 1: Total Phenol and Flavanoid content

\begin{tabular}{|c|c|c|}
\hline Extract & $\begin{array}{c}\text { Total Phenolic } \\
\text { Content (TPC) } \\
\text { Tannic acid } \\
\text { Equivalents }\end{array}$ & $\begin{array}{c}\text { Total Flavanoid } \\
\text { Content (TFC) } \\
\text { Rutin Equivalents }\end{array}$ \\
\hline Leaves & $13.08 \pm 0.44^{\mathrm{e}}$ & $0.61 \pm 0.009^{\mathrm{f}}$ \\
\hline Hexane & $15.02 \pm 0.53^{\mathrm{b}}$ & $2.5 \pm 0.012^{\mathrm{a}}$ \\
\hline Chloroform & $14.6 \pm 0.33^{\mathrm{bcd}}$ & $1.6 \pm 0.016^{\mathrm{b}}$ \\
\hline Ethyl acetate & $8.18 \pm 0.60^{\mathrm{gh}}$ & $1.5 \pm 0.028^{\mathrm{c}}$ \\
\hline Methanol & $8.14 \pm 0.20^{\mathrm{ghi}^{\mathrm{i}}}$ & $0.3 \pm 0.018^{\mathrm{j}}$ \\
\hline Water & $16.45 \pm 0.61^{\mathrm{a}}$ & $0.49 \pm 0.021^{\mathrm{gh}}$ \\
\hline Stem & $10.82 \pm 0.12^{\mathrm{ef}}$ & $0.84 \pm 0.026^{\mathrm{d}}$ \\
\hline Hexane & $10.88 \pm 0.004^{\mathrm{f}}$ & $0.81 \pm 0.04^{\mathrm{de}}$ \\
\hline Chloroform & $14.6 \pm 0.36^{\mathrm{bc}}$ & $0.5 \pm 0.036^{\mathrm{g}}$ \\
\hline Ethyl acetate & $8.66 \pm 0.44^{\mathrm{g}}$ & $0.4 \pm 0.09^{\mathrm{i}}$ \\
\hline Methanol & & \\
\hline Water &
\end{tabular}

Means with different letters are significantly different according to Duncan's test $(p<0.05)$.

\begin{tabular}{|c|c|c|}
\hline \multicolumn{3}{|c|}{ Table 2: Correlation analysis } \\
\hline Antioxidant activity & Phenolics & Flavanoids \\
\hline DPPH & 0.06 & 0.21 \\
\hline Phosphomolybdenum assay & -0.58 & 0.009 \\
\hline FRAP & 0.419 & 0.306 \\
\hline $\mathrm{H}_{2} \mathrm{O}_{2}$ scavenging & 0.093 & 0.135 \\
\hline Reducing power assay & 0.400 & 0.035 \\
\hline
\end{tabular}




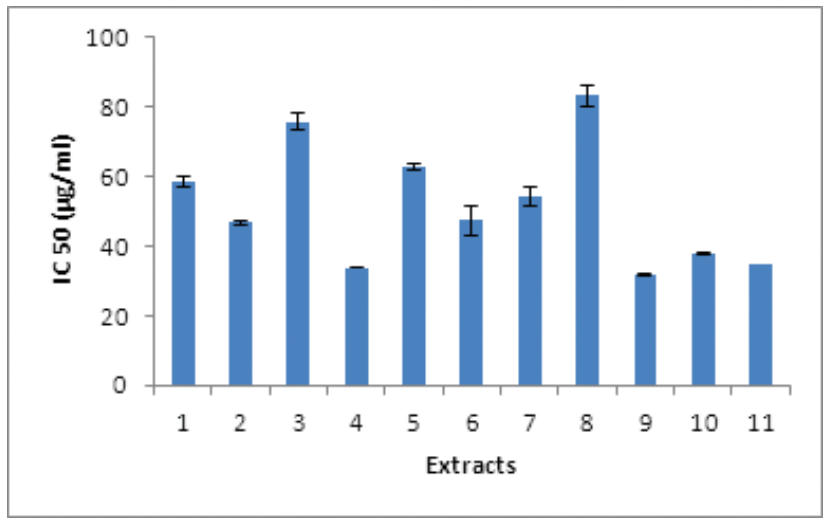

Figure 1: DPPH radical scavenging assay

1- Leaves hexane, 2- Leaves chloroform, 3-Leaves ethyl acetate, 4- Leaves methanol, 5- Leaves water, 6- Stem hexane, 7- Stem chloroform, 8 - Stem ethyl acetate, 9 - Stem methanol, 10 - Stem water, 11- Ascorbic acid.

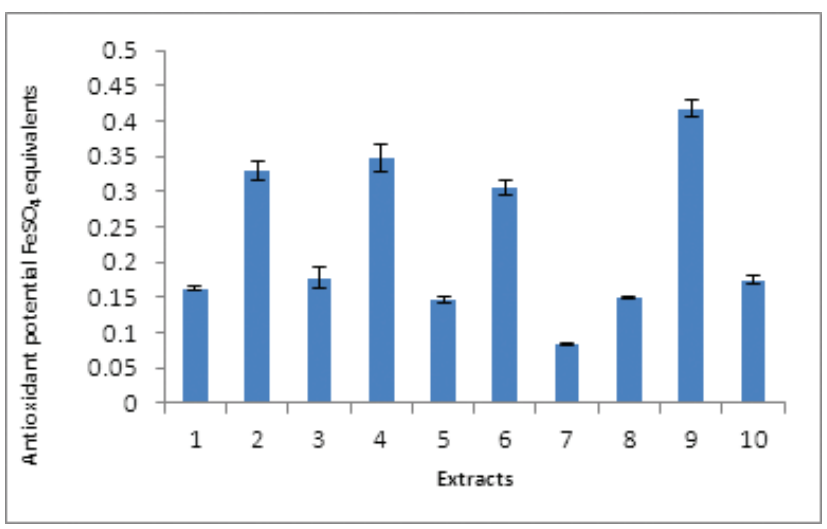

Figure 3: FRAP Assay

1- Leaves hexane, 2- Leaves chloroform, 3-Leaves ethyl acetate, 4- Leaves methanol, 5- Leaves water, 6- Stem hexane, 7- Stem chloroform, 8- Stem ethyl acetate, 9- Stem methanol, 10- Stem water.

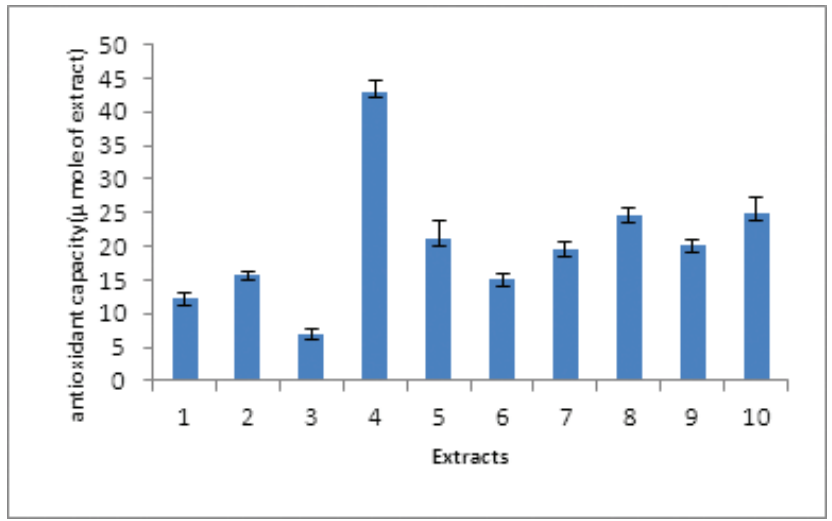

Figure 2: Phosphomolybdenum assay

1- Leaves hexane, 2- Leaves chloroform, 3-Leaves ethyl acetate, 4- Leaves methanol, 5- Leaves water, 6- Stem hexane, 7- Stem chloroform, 8- Stem ethyl acetate, 9- Stem methanol, 10- Stem water.

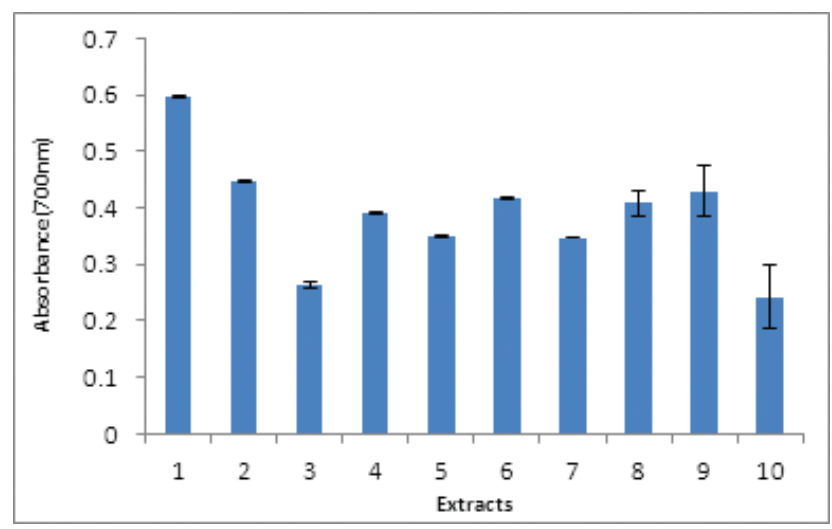

Figure 4: Reducing Power assay

1- Leaves hexane, 2- Leaves chloroform, 3-Leaves ethyl acetate, 4- Leaves methanol, 5- Leaves water, 6- Stem hexane, 7- Stem chloroform, 8- Stem ethyl acetate, 9-Stem methanol, 10- Stem water.

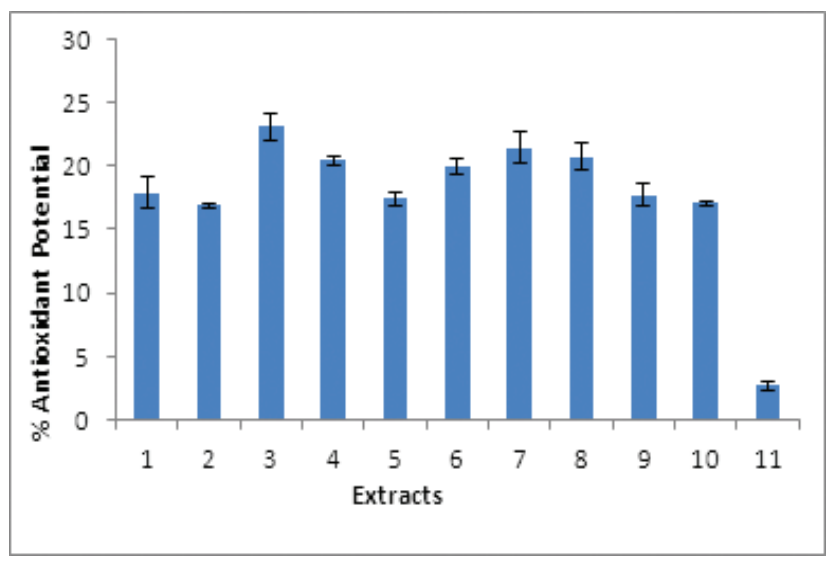

Figure 5: $\mathrm{H}_{2} \mathrm{O}_{2}$ radical scavenging assay

1- Leaves hexane, 2- Leaves chloroform, 3-Leaves ethyl acetate, 4- Leaves methanol, 5- Leaves water, 6- Stem hexane, 7- Stem chloroform, 8- Stem ethyl acetate, 9-Stem methanol, 10-Stem water, 11-ButylatedHydroxytoluene. 
metabolites have synergestic effect and thereby cause elevated antioxidant activity. ${ }^{28}$

As represented in Table 2 Correlation analysis between total phenol and flava $\neg$ noid content showed no relation with the antioxidant activity. These results are in agreement with previous studies conducted in plant species of lamiaceae where no relation was exhibited between antioxidant activity and the antioxidant activity of the polar and non-polar extracts. ${ }^{29}$ The ambiguous relation between the antioxidant activity and the total phenolics is due to numerous reasons. The total phenolic content does not feature all the antioxidants. ${ }^{30}$ Antioxidant properties of single compounds within a group can vary remarkably so that the same levels of phenolics do not necessarily correspond to the same antioxidant responses. Secondary metabolites other than phenols and flavanoids are also responsible for antioxidant activity. ${ }^{31}$ The activity may also come from the other antioxidant secondary metabolites, such as volatile oils, carotenoids and vitamins. Structure and the interaction between the antioxidants is also major factor contributing to antioxidant activity. The antioxidant activity of phenolics mainly depends on the number and the position of hydrogen donating hydroxyl groups on the aromatic cycles of the phenolic molecules. Also it should be mentioned that FolinCiocalteau reagent gives a crude estimate of the total phenolic compounds present in an extract specific for polyphenols, but many interfering compounds such as ascorbic acid and sugars may react with the reagent to give an elevated phenolic concentration. ${ }^{32,33}$ The response of phenolics in the Folin-Ciocalteu assay also depends on their chemical structure. Thus, the radical scavenging activity of an extract cannot be predicted on the basis of its total phenolic content. ${ }^{34}$

\section{CONCLUSION}

The antioxidant activities of the plant extracts largely depend on the composition and concentration of the extracts as well as on the conditions of the test system. The antioxidant activities are influenced by many factors, which cannot be described with one single method. Therefore, it is necessary in this study to perform more than one type of antioxidant activity measurement to take into account the various mechanisms of the antioxidant action. Synergestic action of secondary metabolites is very important property of crude extracts. Presence of various types of secondary metabolites like alkaloids, steroids, tannins, glycosides is responsible for antioxidant activity.Further research focuses on elucidating mechanism of action involved in synergistic action of crude extracts.

\section{ACKNOWLEDGEMENT}

Authors would like to acknowledge financial assistance given by UGC.

\section{CONFLICT OF INTEREST}

Authors declare no conflict of interest.

\section{ABBREVIATION USED}

BHT: Butylated hydroxytoluene; TPC: Total Phenol Content; TFC: Total Flavanoid Content; IC50: Half maximal concentration; Mo: Molybdenum.

\section{REFERENCES}

1. Krinsky NI. Antioxidant functions of carotenoids. Free Radical Biology and Medicine. 1989;7(6):617-35.

2. Gutteridge JM. Lipid peroxidation and antioxidants as biomarkers of tissue damage. Clinical Chemistry. 1995;41(12):1819-28.

3. Sher $\mathrm{H}$ and Alyemeni MN. Ethnobotanical and pharmaceutical evaluation of Capparis spinosa L, validity of local folk and Unani system of medicine. J Med Plants Res. 2010;4(17):1751-6.

4. Boumerfeg S, Ameni D, Adjadj M, Djarmouni M, Khennouf S and Baghiani A. Antihymolytic and Antioxidant Effects of Medicinal Plant Capparis spinosa L. Journal of Life Sciences. 2012;6(6):637.

5. Sen SK and Behera LM. Ethno medicinal plants used by the tribals of Bargarh district to cure diarrhoea and dysentery. Indian J Tradit Knowl. 2008;7(3):425-8.

6. Lansky EP, Paavilainen HM and Lansky S. Caper: the genus Capparis. CRC Press;2013.

7. Kulkarni BG. Flora of Sindhudurg.

8. Rajesh P, Latha S, Selvamani P and Kanna VR. Phytochemical screening and toxicity studies on the leaves of Capparis sepiaria Linn. (Capparidaceae). Journal of Basic and Clinical Pharmacy. 2010;1(1):001.

9. Kanasea VG, Jain BB and Yadav P. Evaluation of in vitro immunomodulatory activity of aqueous and ethanolic extract of Capparis moonii. Int J Pharm Bio Sci. 2013;4(2):344-52.

10. Mallikharjuna PB, Rajanna LN, Seetharam YN and Sharana basappa GK. Phyto chemical studies of Strychnospotatorum Lf-A medicinal plant. Journal of Chemistry. 2007;4(4):510-8.

11. Wani JA, Achur RN and Nema RK. Phytochemical screening and aphrodisiac activity of Asparagus racemosus. Studies. 2011;8:9.

12. Wolfe $\mathrm{K}, \mathrm{Wu} \mathrm{X}$ and Liu RH. Antioxidant activity of apple peels. Journal of Agricultural and Food Chemistry. 2003;51(3):609-14.

13. Ordonez AA, Gomez JD and Vattuone MA. Antioxidant activities of Sechiumedule (Jacq.) Swartz extracts. Food Chemistry. 2006;97(3):452-8.

14. Miliauskas G, Venskutonis PR and Van Beek TA. Screening of radical scavenging activity of some medicinal and aromatic plant extracts. Food Chemistry. 2004;85(2):231-7.

15. Prieto $P$, Pineda $M$ and Aguilar $M$. Spectrophotometric quantitation of antioxidant capacity through the formation of a phosphomolybdenum complex: specific application to the determination of vitamin E. Analytical Biochemistry. 1999;269(2):337-41.

16. Wong CC, Li HB, Cheng KW and Chen F. A systematic survey of antioxidant activity of 30 Chinese medicinal plants using the ferric reducing antioxidant power assay. Food Chemistry. 2006;97(4):705-11.

17. Ferreira IC, Baptista P, Vilas-Boas $M$ and Barros L. Free-radical scavenging capacity and reducing power of wild edible mushrooms from northeast Portugal: Individual cap and stipe activity. Food Chemistry. 2007;100(4):1511-6. 
18. Ruch RJ, Cheng SJ and Klaunig JE. Prevention of cytotoxicity and inhibition of intercellular communication by antioxidant catechins isolated from Chinese green tea. Carcinogenesis.1989;10(6):1003-8.

19. Fejes $\mathrm{S}$, Blázovics A, Lugasi A, Lemberkovics É, Petri $\mathrm{G}$ and Kéry Á. In vitro antioxidant activity of Anthriscus cerefolium L. (Hoffm.) extracts. Journal of Ethnopharmacology. 2000;69(3):259-65.

20. TsUDA Y. Nematocidal Activity of Turmeric: Synergistic Action of Curcuminoids. Chem Pharm Bull. 1993;41(9):1640-3.

21. Verpoorte R. Exploration of nature's Chemodiversity: The role of secondary metabolites as leads in drug development. Drug Discovery Today. 1998;3(5):232-8.

22. Basri DF, Sandra V. Synergistic Interaction of Methanol Extract from Canarium odontophyllum Miq. Leaf in Combination with Oxacillin against MethicillinResistant Staphylococcus aureus (MRSA) ATCC 33591. International Journal of Microbiology. 2016;2016.

23. Keith CT, Borisy AA and Stockwell BR. Multicomponent therapeutics for networked systems. Nature Reviews Drug Discovery. 2005;4(1):71-8.

24. Schmidt BM, Ribnicky DM, Lipsky PE and Raskin I. Revisiting the ancient concept of botanical therapeutics. Nature Chemical Biology. 2007;3(7):360-6.

25. Csermely $\mathrm{P}$, Agoston $\mathrm{V}$ and Pongor $\mathrm{S}$. The efficiency of multi-target drugs: the network approach might help drug design. Trends in Pharmacological Sciences. 2005;26(4):178-82.

26. Huang SL, Guo AX, Xiang Y, Wand XB, Lin HX and Fu L. Clinical study on the treatment of acute Promyelocytic leukemia with Composite Indigo Naturalis tablets. Chin J Hematol. 1995;16:26-8.

27. Cefarelli G, D'Abrosca B, Fiorentino A, Izzo A, Mastellone C, Pacifico S and Piscopo V. Free-radical-scavenging and antioxidant activities of secondary

\section{PICTORIAL ABSTRACT}

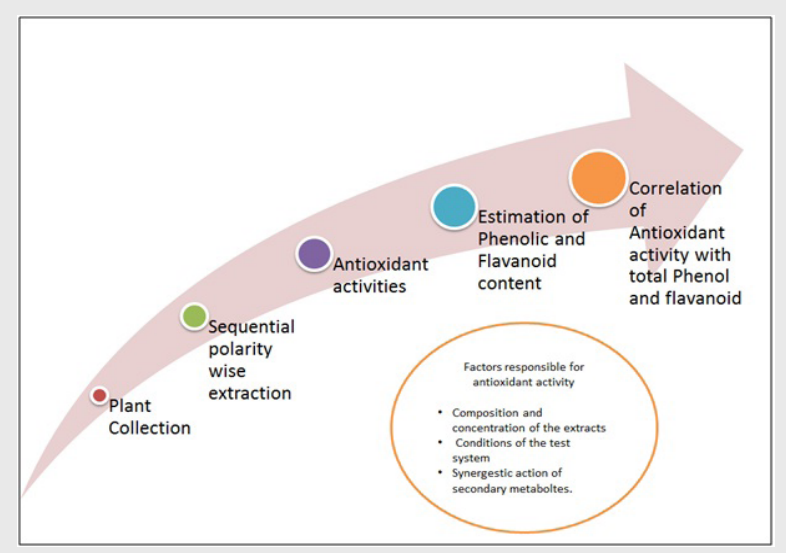

metabolites from reddened cv. Annurca apple fruits. Journal of Agricultural and Food Chemistry. 2006;54(3):803-9.

28. Altunkaya A, Gökmen $V$ and Skibsted LH. pH dependent antioxidant activity of lettuce (L. sativa) and synergism with added phenolic antioxidants. Food Chemistry. 2016;190:25-32.

29. Lagouri V, Bantouna A and Stathopoulos P. A comparison of the antioxidant activity and phenolic content of nonpolar and polar extracts obtained from four endemic lamiaceae species grown in Greece. Journal of Food Processing and Preservation. 2010;34(5):872-86.

30. Djeridane A, Yousfi M, Nadjemi B, Boutassouna D, Stocker P and Vidal N. Antioxidant activity of some Algerian medicinal plants extracts containing phenolic compounds. Food Chemistry. 2006;97(4):654-60

31. Javanmardi J, Stushnoff C, Locke E and Vivanco JM. Antioxidant activity and total phenolic content of Iranian Ocimum accessions. Food Chemistry. 2003;83(4):547-50.

32. Prior RL, Wu X and Schaich K. Standardized methods for the determination of antioxidant capacity and phenolics in foods and dietary supplements. Journal of Agricultural and Food Chemistry. 2005;53(10):4290-302.

33. Granato D, Santos JS, Maciel LG and Nunes DS. Chemical perspective and criticism on selected analytical methods used to estimate the total content of phenolic compounds in food matrices. TrAC Trends in Analytical Chemistry. 2016;15:266-79.

34. Parejo I, Viladomat F, Bastida J, Rosas-Romero A, Flerlage N, Burillo J. and Codina C. Comparison between the radical scavenging activity and antioxidant activity of six distilled and nondistilled Mediterranean herbs and aromatic plants. Journal of Agricultural and Food Chemistry. 2002;50(23):6882-90.

\section{SUMMARY}

- Capparis mooii Wight is an endemic plant belonging to Family Capparidaceae is endemic to Indian subcontinent.

- This plant is commonly known as Waghati in Marathi and Rudanti in sanskrit. Rudanti possess several therapeutic properties a mentioned in Ayurveda

- Our findings reveal potency of crude extracts as compared to standard antioxidants. Therefore synergestic action of compounds is the mechanism postulated for the presence of antioxidant activity. 